\title{
COMPLETE CHARACTERIZATION OF WHEAT STRAW (TRITICUM AESTIVUM PBW-343 L. EMEND. FIORI \& PAOL.) - A RENEWABLE SOURCE OF FIBRES FOR PULP AND PAPER MAKING
}

\author{
Shalini Singh, Dharm Dutt, ${ }^{\mathrm{a}}$ and C. H. Tyagi \\ Triticum aestivum PBW-343 is grown in most of the regions of India, and \\ it is one of the renewable sources most suitable for papermaking. \\ Anatomical studies illustrate that vascular bundles near the periphery \\ contain a strong sheath of sclerenchyma cells, which constitutes about \\ $80 \%$ of the fibers. The total fibers in wheat straw are about $39.20 \%$, and \\ parenchyma and epidermal cells account for 32.10 , and $23.56 \%$, \\ respectively, of the total cells. The dimensions of wheat straw fibers are: \\ average fiber length $1.18 \mathrm{~mm}$, fiber width $13.60 \mu \mathrm{m}$, lumen diameter 5.68 \\ $\mu \mathrm{m}$, and cell wall thickness $3.96 \mu \mathrm{m}$. The dimensions of non-fibrous cells \\ are: parenchyma $445 \times 124 \mu \mathrm{m}$, vessels $96 \times 57 \mu \mathrm{m}$, and epidermal cells \\ $390 \times 38 \mu \mathrm{m}$, which lie between the corresponding values for rice straw, \\ and bagasse. Flexibility coefficients and Runkel ratio of wheat straw fires \\ are quite comparable to bamboo. The low lignin contents of wheat straw \\ reflect that it requires mild cooking conditions; however, hemicelluloses \\ are on higher side. Addition of $A Q$ under optimum soda cooking \\ conditions improves pulp yield by $0.75 \%$, and lowers kappa number by \\ $26.1 \%$. Optimum strength properties are obtained at $45 \pm 1{ }^{\circ} \mathrm{SR}$ except \\ tear index, which declines with increased refining. The fine contents are \\ much higher, and relatively comparable to Eucalyptus tereticornis in \\ terms of curl index and kinks per mm.
}

Keywords: Triticum aestivumPBW-343 (Wheat straw); Anatomy, Morphology; Proximate chemical analysis; Soda pulping; Paper properties; Scanning electron microscopy

Contact information: a: Department of Paper Technology, Indian Institute of Technology Roorkee, Saharanpur Campus, Saharanpur, 247001, India; *Correspondingauthor: dharm_dutt@yahoo.com

\section{INTRODUCTION}

World demand for paper and paperboard is estimated to grow from 300 million tons (Hurter 1997) to over 490 tonnes by the year 2020 (John 2006) with an average rate of $2.8 \%$ per annum. Currently, India produces about 5.6 million tonnes of paper and paper-board per year, which accounts for about $1.6 \%$ of the world's production. Forest cover in India is 67.8 million ha, or $20.6 \%$ of the country's surface area. This translates into a per capita forest area of only 0.8 ha per person, one of the lowest in the world. Total fiber consumption for paper and paperboard production in India will nearly be doubled between 2006 and 2016, growing from 7.4 to 13.7 million tonnes in that time frame. India's total wood fiber deficit is forecast to increase at an annual rate of $11.3 \%$ by 2016 (Flynn 2007). Depleting forest resources are forcing the Indian pulp and paper 
industry to use various alternate fibrous resources, such as non-woody plants including Cannabis sativa, Ipomea carnea (Dutt et al. 2008, 2009a, 2010a), Hibiscus cannabinus, Hibiscus sabdariffa (Upadhyaya et al. 2008, Dutt et al. 2009b, 2010b, 2010c), Sesbania aculeata, Sesbania sesban (Dutt et al. 2004, 2005), and Cymbopogon martini (Dutt et al., 2010d, 2007a), lemon and sofia grass (Kaur et al. 2011) as well as agricultural residues such as sugarcane bagasse (Agnihotri et al. 2010), fast growing hardwoods via. social forestry such as Anthocephalus cadamba, Casurina equisetafolia, and Leucaena leucocephala (Lal et al. 2010; Malik et al. 2004), and waste papers. Annual plant pulping is gaining more and more importance, particularly in countries with deficient wood resources. The share of agro-based fiber use by the paper industry is only $9 \%$ in 1970 , which has been increased to $31 \%$ in 2000 (Anonymous 2005a).

Wheat straw is one of the most important agricultural residues. It is an annually renewable fiber resource that is available in abundant quantity in many regions of the world. India is the second largest producer of wheat in the world, with production hovering around 68 to 75 million tonnes for the past few years. It accounts for approximately $12 \%$ of world's wheat production, and is the second largest wheat consumer after China (FAO 2004). The latest estimated demand for wheat production for the year 2020 is approximately 87.5 million tonnes, or about 13 million tonnes more than the record production of 75 million tonnes harvested in the 199-2000 crop season (Nagarajan 2005). In India, three species of wheat are cultivated: Triticum aestivum, Triticum durum, and Triticum dicoccum (Gupta 2004). Although around 60 varieties are grown by farmers in the various zones, only a few varieties occupy substantial area (Nagarajan 2005). Presently, the most dominant variety in India is Triticum aestivum PBW-343, which occupies around 6 million ha (Joshi et al. 2007).

Many inherent problems are due to the high content of small parenchyma cells in grass and straw tissue, giving a high content of so-called primary fines in the pulp (Ilvasasslo-Pfäffli 1995). These cells further disintegrate during the beating operation, giving an additional quantity of so-called secondary fines. This results in a very high drainage resistance on washing, in filters for thickening, and on the paper machine. The tendency for the pulp to stick to the wet presses, and the low (wet)-strength giving a high web-break frequency of the paper machine, may also be blamed on the high fines content (Rydholm 1965). Deniz (1994) showed that about 32.5\% of the cells in straw are fibers; while the remaining $67.5 \%$ consists of non-fibrous cells, e.g. parenchyma, epidermis cells, vessels, and spirals. The majority of these non-fibrous cells are short in length, and they cause poor drainage in wheat straw pulp (Jacobs 1999). The chemical pulping of wheat straw presents two major problems associated with silica. It causes rather serious difficulties during recovery and poor drainage of straw pulp during papermaking (Tandon et al. 1989; Deniz 1994). The pith containing less-lignified, thin-walled parenchyma also plugs the sheet, impairing drainage, and is easily crushed during refining, perhaps causing further drainage problems. Pith removal reduces the amount of parenchyma cells in the wheat straw pulp (Erŏglu and Deniz 1993; Watson and Garner 1997). It has been shown that even though the fine fraction increases the water retention value and Schopper Reigler value, the fines from wheat straw pulps do not contribute to strength (Ljusgren et al. 2006; Guo et al. 2009). In this regard, Erŏglu and Deniz (1993) examined predesilication of wheat straw with different chemicals, such as $\mathrm{NaOH}, \mathrm{Na}_{2} \mathrm{CO}_{3}$, 
$\mathrm{Na}_{2} \mathrm{~S}+\mathrm{Na}_{2} \mathrm{SO}_{4}$, and $\mathrm{HF}$ (hydrofluoric acid). A remarkably high specific light scattering coefficient at low surface roughness is found for wheat straw (Thykesson et al. 1998). The presence of extractives can also influence the wettability of materials (Young 1976; Hes and Kuo 1988). The low wettability is related to the existence of non-polar extractives (Nguyen and Johns 1979). Generally, there is a waxy layer on the crop material surface (Sauter 1996; Loxton and Hague 1996). Erŏglu and Utsa (1989) studied oxygen delignification of wheat straw pulp produced from the soda-oxygen process and concluded that optimum oxygen delignification is achieved under the following conditions: $\mathrm{NaOH} 4 \%$, retention time $20 \mathrm{~min}$ at $110^{\circ} \mathrm{C}$, oxygen pressure $1 \mathrm{MPa}$, and $12.5 \%$ consistency. During bleaching, the brightness increases from $45.3 \%$ to $64.2 \%$ (ISO), and the pulp strength is almost unchanged. But yield after bleaching is only $82.5 \%$ of the unbleached pulp yield. Wheat straw has better quality for papermaking compared to other non-wood fibers, such as sunflower stalks, vine shoots, cotton stalks due to its stronger breaking length.

Keeping these considerations in view, to ascertain supply of wheat straw for a longer period to pulp and paper industry, a complete characterization of straws from $T$. aestivum PBW-343 was carried out, which covers (a) anatomical, morphological, and chemical characterizations, (b) optimization of soda-anthraquinone (AQ) pulping, (c) optimization of mechanical action given to the fibers $\left({ }^{\circ} \mathrm{SR}\right)$ to get mechanical strength, and (d) scanning electron microscopy (SEM) of soda-AQ fibers.

\section{MATERIALS AND METHODS}

\section{Pretreatment of the Raw Material}

The procured straw was washed with water to remove extraneous dirt, sand, nodes, and other foreign materials. The washed material was air-dried, and then stored in polyethylene bags under dry conditions for experimental work.

\section{Morphological and Anatomical Characterization of Wheat Straw}

In order to get representative results of anatomical and morphological studies, three randomly selected samples of wheat straw were taken from a storage bag. For fibre length determination, small slivers were obtained, macerated with $10 \mathrm{~mL}$ of $67 \% \mathrm{HNO}_{3}$, and boiled in a water bath $\left(100 \pm 2^{\circ} \mathrm{C}\right)$ for $10 \mathrm{~min}$ (Ogbonnaya et al. 1997). The slivers were then washed, placed in small flasks with $50 \mathrm{~mL}$ of distilled water, and the fiber bundles were separated into individual fibers using a small mixer with a plastic end to avoid fiber breaking. The macerated fiber suspension was finally placed on a slide (standard, $7.5 \mathrm{~cm} \mathrm{X} 2.5 \mathrm{~cm}$ ) by means of a dropper (Hans et al. 1999). For fiber diameter, lumen diameter, and cell wall thickness determination, cross-sections were cut on Lietz base sladge microtome 1300. These cross-sections were stained with 1:1 aniline sulphateglycerine mixture to enhance cell wall visibility (cell walls retain a characteristic yellowish colour).

All fiber samples were viewed under a calibrated microscope; a total of 75 randomly chosen fibers were measured. Three derived values were also calculated using fiber dimensions: slenderness ratio as fiber length/fiber diameter, flexibility coefficient as 
(fiber lumen diameter/fiber diameter $) \times 100$ and Runkel ratio as $(2 \times$ fiber cell wall thickness)/ lumen diameter (Saikia et al. 1999). Microscopic slides were also prepared in order to enumerate various cell types present, and their frequency of occurrence. The dimensions of different cell types were also determined microscopically. The results were compared with rice straw and bagasse, as per TAPPI standard test method, T259 sp-98 (Anonymous 1996). The results for morphological characteristics were comparable to hardwoods such as Populus deltoides (Akhtar 2000), and grass such as bamboo (Dutt et al. 2009a).

\section{Chemical Characterization of Wheat Straw}

$100 \mathrm{~g}$ of wheat straw was milled into a powder in a laboratory Wiley mill (Weverk, A- 47054, Sweden), and a fraction passing through -48 mesh size but retained on +80 mesh size was used for chemical analysis. The chemical characterization of wheat straw was carried out as per TAPPI Standard Test methods (Anonymous 2007), except test for silica, which was carried out as per SCAN Test methods (SCAN-C9:62, 1978). The tests that were carried out included: cold and hot water solubility (T207 om-99), 1\% $\mathrm{NaOH}$ solubility (T212 om-98), alcohol-benzene solubility (1:2 v/v) (T204 cm-97), lignin (T222 om-02), pentosan (T223 cm-01), holocellulose ( T249 cm-00), $\alpha$-cellulose (T203 om-88), ash (T211 om-93), and silica (SCAN-C9:62). Three determinations were made for each test, and the results are presented as the mean \pm standard deviation (SD) of the values. The results were compared with Populus deltoides (Akhtar 2000), bagasse (Agnihotri et al. 2010), and rice straw (Goyal and Ray 1989).

The determination of carbon was done in a Leco SC-144DR instrument using direct combustion and infrared detection. In nitrogen determination, the sample is dropped into a hot furnace and flushed with pure oxygen for very rapid combustion, and by-products of combustion are formed $\left(\mathrm{CO}_{2}, \mathrm{H}_{2} \mathrm{O}, \mathrm{NO}_{\mathrm{x}}\right.$, and $\left.\mathrm{N}_{2}\right)$. The material then is passed through the furnace filter and thermoelectric cooler for subsequent collection in a ballast apparatus. These collected gases in the ballast are mixed, and a small aliquot dose is then used for further conversion of the gases. The remaining aliquot that has been reduced is measured by the thermal conductivity cell for nitrogen, in a Leco FP-528. Two determinations per sample were performed according to CEN/TS 15104 (Anonymous $2005 \mathrm{~b}$ ) to determine the carbon and nitrogen contents.

A Leco TruSpec TRSCHNC was used to determine hydrogen. The system is based on the Dumas method of combustion. There are three phases during an analysis cycle: purge, burn, and analyze. In the sample-drop purge phase, the encapsulated sample is placed in the loading head, sealed, and purged of any atmospheric gases that have entered during sample loading. The ballast volume (zero volume at this point) and gas lines are also purged. During the burn phase, the sample is dropped into the primary furnace $\left(950^{\circ} \mathrm{C}\right)$, and flushed with pure oxygen for very rapid combustion. The products of combustion are passed through the after-burner furnace, furnace filter, pre-cooler, and thermoelectric cooler before being collected in the ballast volume. In the analysis phase, the combustion gases in the ballast become homogeneous by means of passive mixing. A series of infrared detectors measure the evolved gases for hydrogen. In addition, a $3 \mathrm{~cm}^{3}$ aliquot captured in a loop before the ballast piston is forced down to evacuate the ballast. 
An optimized detector was used for hydrogen. The final result was displayed as weight percentage, according to CEN/TS 15104 (2005b).

\section{Pulping Studies}

The wheat straw was digested in Weverk electrically heated rotary digester of $0.02 \mathrm{~m}^{3}$ capacity having four bombs, each of $1 \mathrm{~L}$ capacity. It was cooked under different cooking conditions such as, maximum temperature ranging from 130 to $160^{\circ} \mathrm{C}$, cooking time from 15 to $150 \mathrm{~min}$, active alkali from 9 to $16 \%$ (as $\mathrm{Na}_{2} \mathrm{O}$ ), and liquor to raw material ratio of $4: 1$. Based on experimental results at optimum cooking conditions, $0.1 \%$ AQ, a carbohydrate stabilizer, was added (based on o. d. raw material) to study its impact on pulp yield, screening rejects, and kappa number, while keeping the other operating parameters constant. Wheat straw was also delignified at varying active alkali doses ranging from 10 to $12 \%\left(\right.$ as $\mathrm{Na}_{2} \mathrm{O}$ ) in the presence of $0.1 \%$ AQ while keeping other operating parameters constant. After completion of cooking, the pulp was washed on a laboratory flat stationary screen having 300 mesh wire bottom for the removal of residual cooking chemicals. The pulp was disintegrated and screened through Weverk vibratory flat screen with slot size of $0.15 \mathrm{~mm}$, and the screened pulp was washed, pressed and crumbled. The pulp was then analyzed for kappa number (T236 cm-85), pulp yield, and lignin (T222 om-88) and screening rejects as per TAPPI Standard Test Methods (Anonymous 2007).

\section{Fiber Classification Studies}

The fiber fractionation of soda-AQ pulps of wheat straw was carried out with the help of a Bauer-McNett fiber classifier (T233 cm-06) as per TAPPI Standard Test Methods (Anonymous 2007). The mesh screen numbers were 20, 48, 100, and 200.

\section{Preparation of Laboratory Handsheets and Evaluation of Paper Properties}

The unbleached pulp was beaten in a PFI mill (T200 sp-96) to different beating levels. Laboratory handsheets of $60 \mathrm{~g} / \mathrm{m}^{2}$ were prepared (T221 cm-99), and tested for tear index (T414 om-98), tensile index (T494 om-01), burst index (T403 om-97), and double fold numbers (T423 cm-98) as per TAPPI standard test methods (Anonymous 2007).

\section{Studies on Fiber Deformation}

A pulp suspension at $0.02 \%$ consistency was prepared and used for analysis of various fiber characteristics (curl index, number of shives per mm and kink index) by using Hi-Resolution Fiber Quality Analyzer, Model V1.3REB19CV-M 4.

\section{Light Microscopy}

The morphological features of the fibers were studied using light microscopy. Pulp fibers were simply boiled in lacto-phenol for $10 \mathrm{~min}$, and then microscopic slides were prepared. These slides were then observed under light microscope (WILL-OPTIK Wetzlar-Nbn, Germany) at different magnifications.

\section{Scanning Electron Microscopy}

Scanning electron microscopy (SEM) of the soda-AQ pulp samples was carried 
out at using a scanning electron microscope, Model SEM, Leo 435 VP, England. Samples for microscopy were prepared by subjecting the pulp samples to fixation using $3 \%(\mathrm{v} / \mathrm{v})$ glutaraldehyde-2\% (v/v) formaldehyde (4:1) for $24 \mathrm{~h}$. Following the primary fixation, samples were washed thrice with double distilled water. The samples were then treated with the ethyl alcohol of different concentrations i.e. 30, 50, 70, 80, 90, and $100 \%$ for dehydration. Samples were kept for 15 min each up to $70 \%$ alcohol gradient, thereafter treated for $30 \mathrm{~min}$ each, for subsequent alcohol gradients. After treating with 100\% alcohol, samples were air dried and examined under SEM using gold shadowing technique (Cheng et al., 1994). Electron photomicrographs were taken at $15 \mathrm{kV}$ using detector SE1 and at desired magnifications.

\section{Statistical Analysis}

For determination of kappa number, three experimental values were taken in each case and the results are the mean \pm standard (SD) of the values.

\section{RESULTS AND DISCUSSION}

Microphotograph 1 shows a transverse section (T.S.) of wheat straw internodes, revealing its anatomical features at a magnification of $10 \mathrm{X}$. The primary wall of collenchymatous cells (A) is composed of cellulose and pectin compounds. At maturity, the collenchymatous cells become lignified and thickened to form sclerenchymatous cells (B), which give rigidity to the stem. Sclerenchymatous cells are thick walled and lignified, but sometimes in the phloem region a bundle of sclerenchyma cells is found;

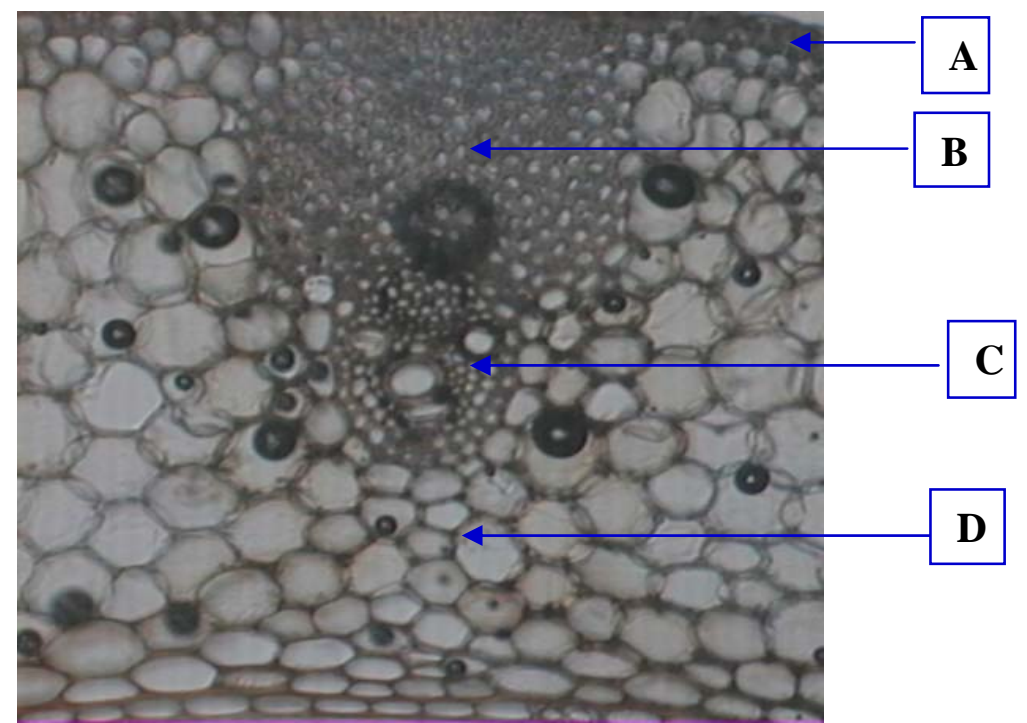

Microphotographs 1. Transverse section (T.S.) of wheat straw internodes showing different types of cells (A) epidermis, (b) sclerenchymas (bast fibers), (c) vascular bundle, and (d) parenchyma (ground tissue) (10x) 
then these cells are called bast fibers or phloem fibers. The conductive tissues or vascular bundles (C) near the periphery are fused with each other by a strong sheath of sclerenchyma cells or bast fibers. The larger bundles in the inner circle are embedded into a large ground tissue of parenchymatous cells. These two circles of vascular bundles have a considerable amount of extra vascular fibers, which have good paper-making value. Under the microscope, most of the useful fibers are located at the outer part of the stem (near the skin) with a little area of the fibers being present in the vascular bundle. The fibers originating from the outer part of internodes are thick walled, and those coming from the inner part are called thin walled. However, the bulk of the fibers $(80 \%)$ are from the outer part of stem. The ground tissue is composed of parenchyma cells (D). They gradually change their chemical composition and dimensions during growth in ways that vary from plant to plant. These cells pose a problem of fluff during drying or on printing machines due to larger surface area of the non-fibrous cells (Dutt et al. 2007b). This complexity of the ground tissue is a great problem to the papermakers. Therefore, processing and efficient screening systems must be developed for each raw material exclusively, taking into consideration its specific morphology. While wheat straw fines reduce freeness and increase the water retention, they also improve the tensile strength of unbeaten pulp as the thin-walled parenchyma collapse, thereby aiding in bonding and contributing to the tensile strength (Watson and Garner 1997). The epidermis is followed by 2 to 3 layers of rectangular collenchyma cells that have an unevenly thickened cell wall and function as a supporting tissue.

The dimensions of various non-fibrous cells of wheat straw pulp are comparable to those of rice straw and bagasse (Anonymous 2007). The parenchyma cells are $445 \mu \mathrm{m}$ long and $124 \mu \mathrm{m}$ wide, vessels $96 \mu \mathrm{m}$ long and $57 \mu \mathrm{m}$ wide, and epidermal cells $390 \mu \mathrm{m}$ long and $38 \mu \mathrm{m}$ wide. The dimensions of parenchymatous cells of wheat straw lie between those of rice straw and bagasse. Therefore, the slot size of the screen should be selected according to the morphology of wheat straw. This may help to solve the problem of fluff during offset lithographic printing for paper made from wheat straw pulp. Microphotographs 2 A-D show wheat straw fibres, along with parenchymal and epidermal cells. The protoxylem has strong lignified cell wall, which is resistant to pulping. Similarly, thick walled parenchymatous cells are also resistant to chemical treatment, and difficult to screen out due to their larger cell dimensions. The protoxylem vessels have an extreme length and a very undesirable shape, which might form coarse tangles in the pulp and the phloem fibers form the characteristic shape of the vascular bundle.

Table 2 shows the morphological characteristics of wheat straw fibers, and their comparison with those of $P$. deltoides (Akhtar 2007) and bamboo (Dutt et al. 2009a). The total fibers in wheat straw are about $39.20 \%$, compared to $50 \%$ in $P$. deltoides. Therefore, wheat straw produces lesser pulp yield compared to $P$. deltoides. The parenchyma, epidermal and vessel cells account for $32.10,5.14$, and $23.56 \%$, respectively of the total cells. These fines have large surface area (Marton and Marton 1980) and may act as fillers. They may adversely affect the mechanical strength properties of paper. The vessels account for about $5.14 \%$ of the total cells, compared to $32.40 \%$ in P. deltoides. Vessels have blunt ends, perforated end walls, and have pits of various shapes. The fibers of wheat straw are slender with sharply pointed ends, and with an average fiber length of 
$1.18 \mathrm{~mm}$ compared to $0.984 \mathrm{~mm}$ for $P$. deltoides and $1.70 \mathrm{~mm}$ for bamboo. The average fiber width of wheat straw fiber is $13.60 \mu \mathrm{m}$ compared to $25.60 \mu \mathrm{m}$ for P. Deltoids, and $23.60 \mu \mathrm{m}$ for bamboo. The lumen of wheat straw fiber is narrow having a diameter of $5.68 \mu \mathrm{m}$ compared to $17.60 \mu \mathrm{m}$ for P. Deltoids, and $9.50 \mu \mathrm{m}$ for bamboo. The cell wall thickness of wheat straw fibers is $3.96 \mu \mathrm{m}$, which almost resembles to that of $P$. deltoides, whereas, it is lower than that for bamboo fibers. The slenderness ratio of wheat straw fibers is 41.76 , against a slenderness ratio of 72.03 for bamboo and 38.43 for $P$. deltoides. The slenderness ratio (L/D), which is also termed the felting power, is inversely proportional to the fiber diameter. Fibers having high slenderness ratio have a low degree of collapsing and conformability, and such types of paper gives more tear, porosity, bulk, and opacity (Reddy and Young 2005). A low slenderness ratio means a reduced tearing resistance, which is partly because the short and thick fibers do not produce good surface contact and fiber-to-fiber bonding (Ogbonnaya et al. 1997).
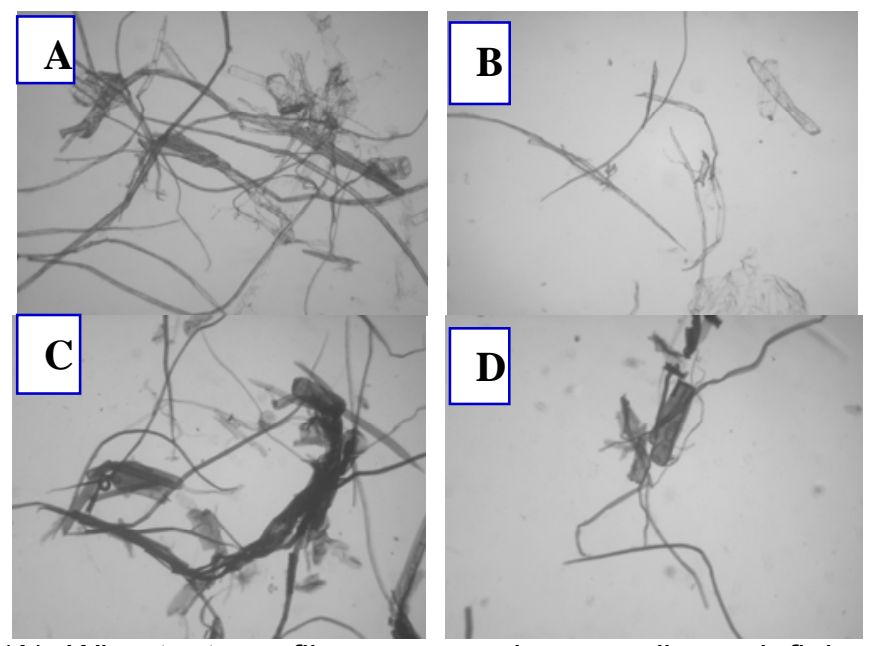

Microphotographs 2. (A) Wheat straw fibers, parenchyma cells and flakes of thin walled parenchyma (4X) (B) Wheat straw fibers with vessels, thick and thin walled parenchyma cells (10x). (C) Wheat straw fibers with flakes of epidermal cells and vessel bundles (10x) (D) Wheat straw fibers with a prominent parenchyma cell and flakes of epidermal cells (10x)

When used for applications such as paper, the slenderness ratio of individual cells in a fiber affects the flexibility and resistance to rupture of the fibers (Maiti 1997). The flexibility coefficient of wheat straw fibers is 41.76, which almost resembles that of bamboo fibers but is much less than that of $P$. deltoides fibres. Such types of fibers do not collapse readily to form double-walled ribbons, and they tend to retain their tubular structure on pressing, thus provide lesser surface contact area for bonding. Sheets made from such types of fibers tend to have greater tear, porosity, bulk, and opacity (Rydholm 1965). The Runkel ratio of wheat straw is almost equal to that of bamboo. Runkel ratio is directly affected by cell wall thickness but not by lumen diameter, and is related to fiber density (Pillow et al. 1941). The breaking length, bursting strength, and double fold are determined by fiber density. The Runkel ratio of wheat straw almost resembles that of bamboo. However, due to a lower fiber diameter, the flexibility and the degree of collapse of fiber, both of which control the degree of conformability within the paper 
sheet and, as such the size and number of inter-fiber bonds, are improved in the case of wheat straw. The mechanical properties, along with other properties of paper related to wet plasticity, may be increased by fibrillation and by the presence of high hemicelluloses (28.95\%) (Table3). The flexibility coefficient and Runkel ratio of wheat straw is also in close proximity with bamboo. Based on morphological characteristics the wheat straw is quite comparable to bamboo. A large amount of hemicelluloses may result in a decrease in tensile and bursting strength, not because of the bonding effect but possibly because the individual fiber strength may be reduced as a result of the decrease in the average molecular weight of the polymer system (Tyagi et al. 2004).

Table 1. Dimensions of Parenchyma Cells, Epidermal Cells, and Vessels of Wheat Straw

\begin{tabular}{|l|c|c|c|}
\hline Cell type & Wheat straw & $\begin{array}{c}\text { Rice straw } \\
\text { (Anonymous, 2007) }\end{array}$ & $\begin{array}{c}\text { Bagasse } \\
\text { (Anonymous, 2007) }\end{array}$ \\
\hline $\begin{array}{c}\text { Parenchyma cells, } \\
\text { Length, } \mu \mathrm{m}\end{array}$ & $445 \pm 1.09$ & - & 850 \\
Width, $\mu \mathrm{m}$ & $124 \pm 2.02$ & 10.2 to 20.5 & 140 \\
\hline $\begin{array}{c}\text { Epidermal cells, } \\
\text { Length, } \mu \mathrm{m}\end{array}$ & $96 \pm 2.09$ & 350 & 1350 \\
Width, $\mu \mathrm{m}$ & $57 \pm 1.01$ & 82 & 150 \\
\hline Vessels, & $390 \pm 1.08$ & 650 & - \\
Length, $\mu \mathrm{m}$ & $38 \pm 1.10$ & 40 & - \\
Width, $\mu \mathrm{m}$ & & & - \\
\hline
\end{tabular}

\pm Standard deviation from the mean

Table 2. Morphological Characterization of Wheat Straw Fibers

\begin{tabular}{|l|l|l|l|}
\hline Parameters & Wheat straw & $\begin{array}{l}\text { Populus deltoids } \\
\text { (Akhtar, 2007) }\end{array}$ & $\begin{array}{l}\text { Bamboo } \\
\text { (Dutt et al., 2009a) }\end{array}$ \\
\hline Length (L), mm & $1.18 \pm 0.08$ & 0.984 & 1.70 \\
\hline Width (D), $\mu \mathrm{m}$ & $13.60 \pm 1.7$ & 25.60 & 23.60 \\
\hline Lumen (d), $\mu \mathrm{m}$ & $5.68 \pm 1.09$ & 17.60 & 9.50 \\
\hline Thickness (w), $\mu \mathrm{m}$ & $3.96 \pm 0.08$ & 4.10 & 7.00 \\
\hline Slenderness ratio (L/D) & 86.76 & 38.43 & 72.03 \\
\hline Flexibility coefficient (d/DX100) & 41.76 & 68.75 & 40.56 \\
\hline Runkel ratio (2w/d) & 1.39 & 0.465 & 1.47 \\
\hline Fiber, \% & $39.20 \pm 0.06$ & 50.00 & - \\
\hline Parenchyma, \% & $32.10 \pm 0.05$ & - & - \\
\hline Vessels, \% & $5.14 \pm 0.05$ & 32.40 & - \\
\hline Epidermis, \% & $23.56 \pm 0.04$ & - & - \\
\hline
\end{tabular}

\pm Standard deviation from the mean

\section{Chemical Characterization of Wheat Straw}

Table 3 shows the results for chemical characterization of wheat straw, which are compared with rice straw (Goyal and Ray 1989), bagasse (Dutt 1994), and P. deltoides (Akhtar 2000). The cold and hot water solubles in wheat straw are on higher side in comparison to bagasse, rice straw, and $P$. deltoides. This is attributed to the presence of 
higher inorganic compounds, tannins, gums, sugars, and colouring matter present in wheat straw. The higher is the water solubility, the lower will be the pulp yield. The high

Table 3. Chemical Characterization of Wheat Straw

\begin{tabular}{|l|l|l|l|l|}
\hline Particulars & $\begin{array}{l}\text { Wheat } \\
\text { straw }\end{array}$ & $\begin{array}{l}\text { Populus deltoides } \\
\text { (Akhtar 2000) }\end{array}$ & $\begin{array}{l}\text { Bagasse } \\
\text { (Dutt 1994) }\end{array}$ & $\begin{array}{l}\text { Ricer straw } \\
\text { (Goyal and } \\
\text { Ray 1989) }\end{array}$ \\
\hline Cold water solubility, \% & $14.46 \pm 0.03$ & 3.80 & 5.91 & 4.83 \\
\hline Hot water solubility, \% & $16.59 \pm 0.03$ & 4.50 & 7.85 & 15.21 \\
\hline $1 \%$ NaOH solubility, \% & $39.90 \pm 0.07$ & 19.60 & 33.60 & 49.82 \\
\hline Alcohol-benzene solubility, \% & $4.95 \pm 0.02$ & 2.80 & 6.30 & 4.87 \\
\hline *Holocellulose, \% & $72.15 \pm 0.02$ & 69.40 & 70.60 & 71.96 \\
\hline *Alpha-cellulose, \% & $43.20 \pm 0.02$ & 47.40 & 42.00 & - \\
\hline *Pentosans, \% & $24.50 \pm 0.08$ & 17.30 & 23.85 & 22.00 \\
\hline *Hemicellulose, \% & 28.95 & - & 28.45 & - \\
\hline *Lignin,\% $\%$ & $21.12 \pm 0.06$ & 21.80 & 20.30 & 25.22 \\
\hline Ash, \% & $7.50 \pm 0.02$ & 0.63 & 3.80 & 13.58 \\
\hline Silica, \% & $4.50 \pm 0.08$ & - & 2.10 & 12.18 \\
\hline Hydrogen, \% & 49.0815 & - & - & - \\
\hline **Carbon, \% & 27.2845 & - & - & - \\
\hline **Oxygen, \% & 21.9845 & - & - & - \\
\hline **Nitrogen, \% & 0.4847 & - & - & - \\
\hline
\end{tabular}

\pm Standard deviation from the mean, ${ }^{*}$ Extractive free basis, without ash correction, expressed on o.d. raw material basis, ${ }^{* *}$ Elemental mol \%

$\mathrm{NaOH}$ solubility of wheat straw is due to the presence of low molar mass carbohydrates and other alkali soluble materials. Compared to wheat straw, the degradation of rice straw due to fungal decay, heat, and light is more, but less than bagasse, and $P$. deltoides. The alcohol-benzene solubles in wheat and rice straw are almost same but are on a higher side in bagasse, and on a lower side in $P$. deltoides. This indicates that rice straw and wheat straw contain more of substances like waxes, fats, resins, phytosterols, as well as nonvolatile hydrocarbons, low-molecular-weight carbohydrates, salts, and other watersoluble substances. A higher content of extractives in pulp can have an adverse effect on the runnability of process equipment, and paper made from such type of fibers shows reduced water absorbency (Levitin 1970). Wheat straw has a total carbohydrate fraction (holocellulose) approximately equal to that of hardwood. This is due to the high hemicellulose (mainly pentosans), and low lignin content compared to wood, which is a characteristic feature of agro-residues. This characteristic directly influences the fibrillation of fibers during refining operations. It has been shown that the higher is the hemicelluloses contents, the better will be the swelling behavior of the pulp, which leads to an increase in mechanical strength properties, including tensile, burst indexes, and double folds (Nevell and Zeronian 1985). The $\alpha$-cellulose content of whole straw is $43.20 \%$, which is similar to that of bagasse $(42.00 \%)$. The $\alpha$-cellulose of $P$. deltoides is higher than of wheat straw. A pulp with high $\alpha$-contents shows better strength properties. 
According to the rating system designated by Nieschlag et al. (1960), plant materials with $34 \%$ and higher $\alpha$-cellulose content are characterized as promising for pulp and paper manufacture from a chemical composition point of view. Holocellulose, as a whole, adds to the overall strength of the paper. The lignin content in whole straw is $21.12 \%$, which resembles to that of bagasse $(20.30 \%)$, and $P$. deltoides $(21.80 \%)$. The amount of lignin is directly related to the consumption of cooking liquor and the length of the cooking cycle. Also, the higher the lignin content, the greater will be the stiffness of the fibers (Dutt et al. 2009a). The ash content of wheat straw is $7.5 \%$, which was much higher than that of $P$. deltoides $(0.63 \%)$, and bagasse $(3.80 \%)$ but much lower than that of rice straw $(13.58 \%)$. The silica content in wheat straw is relatively high as compared to wood. Silica causes rather serious difficulties during recovery of pulping chemicals, as well as poor drainage of straw pulp during papermaking (Tandon et al. 1989). At the same time, silica can play a role of inhibitor for $\mathrm{O}_{2}$ delignification and bleaching with $\mathrm{H}_{2} \mathrm{O}_{2}$, thereby eliminating the need for additional inhibitors to mask transition metals ions during pulping/ bleaching (Payton and Canaris 1997). The major elemental constituents of wheat straw are carbon (27.2845\%), oxygen (21.9845\%), and hydrogen (49.0815\%). The elemental contents partially determine energetic properties of agro-residues. Some previous researchers found that calorific value of biomass increases with $\mathrm{C}$ and $\mathrm{H}$ contents (Demirbas 1997). The biomass contains a higher proportion of hydrogen, and carbon content, which increases the energy value. The concentration of nitrogen in wheat straw is $0.4847 \%$. The main environmental impact is the generation of NOx in the chemical recovery furnace (Nussbaumer 2002). Ultimate analysis is very important in order to determine the theoretical air-fuel ratio in thermo-conversion systems, to evaluate the heating values, and also to have knowledge of the pollution potential.

\section{Pulping Studies}

Influence of temperature and time

Figure 1A shows the curves plotted between residual lignin and reaction time at different reaction temperatures. As shown, each curve can be approximated by two straight lines at each temperature investigated. The curve segments having the steeper slopes are attributed to rapid solublization of bulk of lignin (bulk delignification), whereas the parts of curves with more gentle slopes are attributed to the slow solublization of the residual lignin (residual delignification). Both parts of these curves have different velocity constants. The bulk delignification corresponds to the removal of easily assessable lignin present in the middle lamella, and the residual delignification corresponded to the removal of lignin present in the primary wall, secondary wall layers i.e. $\mathrm{S}_{1}, \mathrm{~S}_{2}$, and $\mathrm{S}_{3}$ layers, and the central inter connections cavity, etc. The delignification of wood in alkaline pulping is also associated with the solubilization of significant amounts of hemicelluloses (Kleinert 1965). These curves indicate that as the temperature is decreased from 160 to $130{ }^{\circ} \mathrm{C}$, the reaction time to reach transition from bulk to residual delignification phase and the lignin content of the pulp, corresponding to this transition point, both increase. 

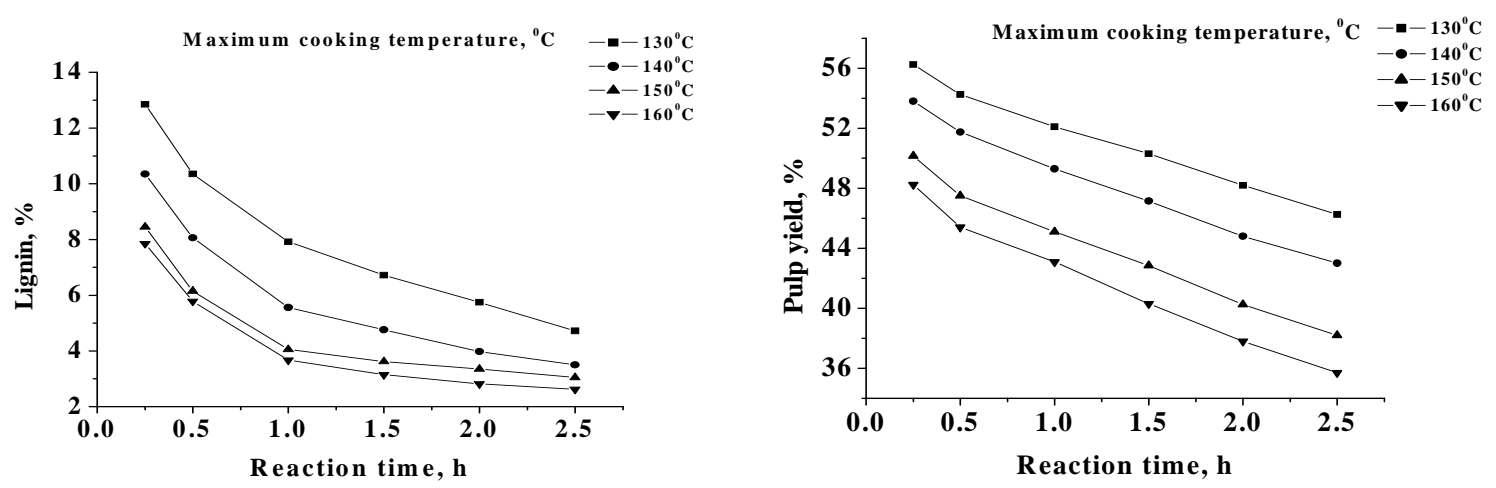

Fig. 1. (A) Curves of lignin vs. different reaction times; (B) Curves of pulp yield vs. different reaction times at maximum cooking temperature during soda pulping of wheat straw.

Table4. Effect of Temperature and Maximum Cooking Time on Pulp Yield, Kappa Number and Lignin of Wheat Straw

\begin{tabular}{|c|c|c|c|c|}
\hline Temperature, ${ }^{\circ} \mathrm{C}$ & $\begin{array}{c}\text { Time at } \\
\text { temperature, } \mathrm{h}\end{array}$ & $\begin{array}{l}\text { Yield, } \\
\%\end{array}$ & Kappa number & $\begin{array}{l}\underset{\%}{\text { Lignin, }} \\
\end{array}$ \\
\hline \multirow{6}{*}{130} & 0.25 & 56.25 & - & 12.85 \\
\hline & 0.50 & 54.25 & - & 10.35 \\
\hline & 1.00 & 52.10 & $45.3 \pm 0.28$ & 7.92 \\
\hline & 1.50 & 50.30 & - & 6.72 \\
\hline & 2.00 & 48.20 & - & 5.75 \\
\hline & 2.50 & 46.25 & - & 4.72 \\
\hline \multirow{6}{*}{140} & 0.25 & 53.80 & - & 10.35 \\
\hline & 0.50 & 51.75 & - & 8.06 \\
\hline & 1.00 & 49.30 & $38.4 \pm 0.31$ & 5.56 \\
\hline & 1.50 & 47.15 & - & 4.76 \\
\hline & 2.00 & 44.80 & - & 3.98 \\
\hline & 2.50 & 43.00 & - & 3.5 \\
\hline \multirow{6}{*}{150} & 0.25 & 50.15 & - & 8.45 \\
\hline & 0.50 & 47.50 & - & 6.15 \\
\hline & 1.00 & 45.10 & $24.70 \pm 0.17$ & 4.05 \\
\hline & 1.50 & 42.85 & - & 3.62 \\
\hline & 2.00 & 40.25 & - & 3.35 \\
\hline & 2.50 & 38.20 & - & 3.05 \\
\hline \multirow{6}{*}{160} & 0.25 & 48.25 & - & 7.85 \\
\hline & 0.50 & 45.40 & - & 5.78 \\
\hline & 1.0 & 43.10 & $22.8 \pm 0.30$ & 3.67 \\
\hline & 1.5 & 40.30 & - & 3.15 \\
\hline & 2.0 & 37.80 & - & 2.82 \\
\hline & 2.5 & 35.70 & - & 2.62 \\
\hline
\end{tabular}

Cooking conditions: Liquor to raw material ratio $=4: 1$, active alkali, $\%\left(\right.$ as $\left.\mathrm{Na}_{2} \mathrm{O}\right)=12$, time from ambient to $105{ }^{\circ} \mathrm{C}, \min =30$, time from 105 to maximum temperature, $\min =30$ 
Table 4 and Fig. 1B also reveal that at lower temperature range, the residual lignin contents decrease sharply, while at higher temperature, the magnitude of decrease in lignin content is not so significant. Moreover, at higher temperature, the degradation of carbohydrate fractions also increases, thereby resulting in a reduced pulp yield (Kleinert 1965). In other words, at the transition point, lower pulp lignin contents are obtained at $150{ }^{\circ} \mathrm{C}$. Beyond a temperature of $150{ }^{\circ} \mathrm{C}$ degradation of carbohydrates contents occurs due to peeling reactions (Hinrichs 1967). After the transition points the curves are almost horizontal lines, which clearly indicates that the bulk delignification does not continue beyond these transition points, and it is not economical to continue the cooking operation beyond this optimum temperature of $150{ }^{\circ} \mathrm{C}$. Therefore, based on experimental data, a maximum cooking time of $1 \mathrm{~h}$ and maximum cooking temperature of $150{ }^{\circ} \mathrm{C}$ may be considered as an optimum cooking condition for the soda pulping of wheat straw.

Figure 2 reveals the effect of maximum cooking temperature ranging from 140 to $160^{\circ} \mathrm{C}$, alkali dose $12 \%\left(\right.$ as $\mathrm{Na}_{2} \mathrm{O}$ ), cooking time $1 \mathrm{~h}$, and liquor to raw material ratio $4: 1$, on screened pulp yield, screening rejects, and kappa number of pulp. Figure 2 indicates that screened pulp yield increases with increasing temperature from 140 to $150{ }^{\circ} \mathrm{C}$, and then follows a declining trend, while both kappa number and screening rejects drop sharply up to a cooking temperature of $150^{\circ} \mathrm{C}$, and then remain practically constant.

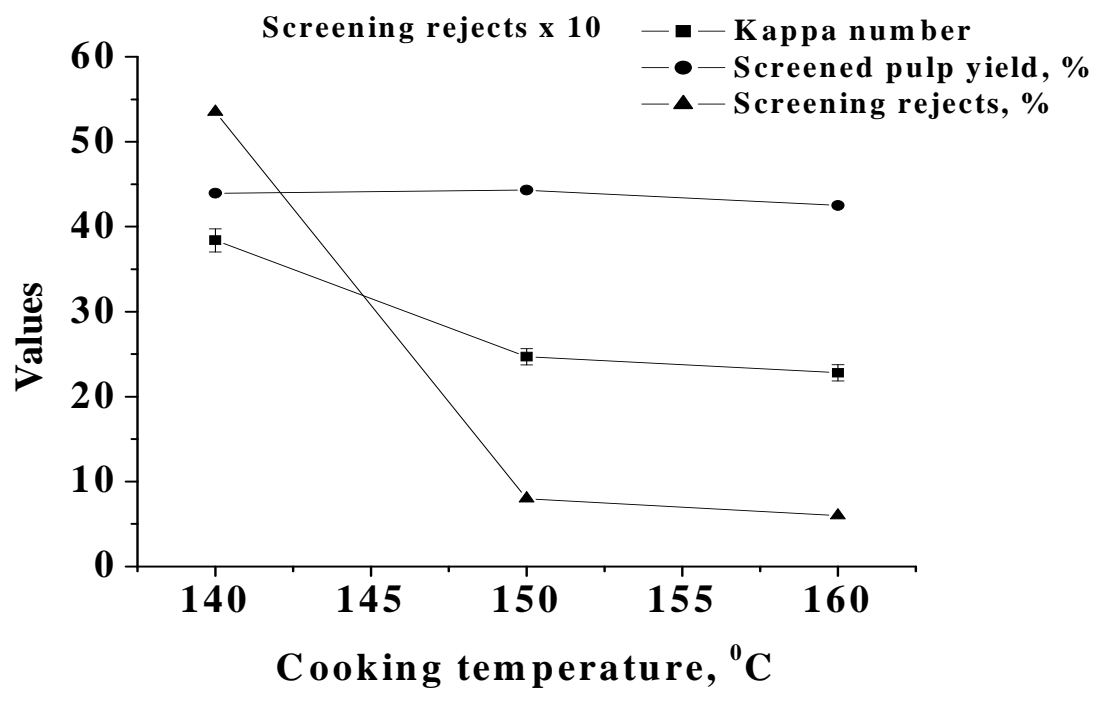

Fig. 2. Effect of maximum cooking temperature on screened pulp yield, screening rejects, and kappa number

\section{Influence of alkali charge}

Figure 3A shows that screened pulp yield increases with increasing active alkali from 9 to $12 \%$ (as $\mathrm{Na}_{2} \mathrm{O}$ ), and then it tends to decline sharply, whereas both kappa number and screening rejects decline sharply up to an alkali dose of $12 \%$. Beyond an alkali dose of $12 \%$, the decrease in kappa number and screening rejects is not so significant. The screened pulp yield of wheat straw is found to be $44.30 \%$ and kappa number 24.70 at an active alkali charge of $12 \%\left(\mathrm{as} \mathrm{Na}_{2} \mathrm{O}\right)$, which may be considered as 
optimum cooking dose for wheat straw. During soda pulping, the consumption of active alkali is found to be constant over a wide range of alkali charge (Lindberg 1960). It is found that the excessive active alkali charge, which remains unconsumed during the course of pulping adversely, affects the pulping viscosity. The wheat straw contains slightly more solubles; therefore, pulp yield per digester will be less.

\section{Influence of time}

Figure 3B shows the effect of cooking time on screened pulp yield, screening rejects, and kappa number during soda pulping of wheat straw, while keeping all other variables constant, such as alkali dose $12 \%\left(\right.$ as $\left.\mathrm{Na}_{2} \mathrm{O}\right)$, liquor to raw material ratio of 4:1, digester pressure $5 \mathrm{~kg} / \mathrm{cm}^{2}$, and maximum cooking temperature $150{ }^{\circ} \mathrm{C}$. When cooking time is increased from 30 to $60 \mathrm{~min}$, the screened pulp yield increases from 40.25 to $44.30 \%$, and kappa number drops from 28.30 to 24.70 . Beyond that, the screened pulp yield drops sharply, while kappa number remains almost constant. Therefore, maximum cooking time of 60 min may be considered as an optimum cooking time for soda pulping of wheat straw.
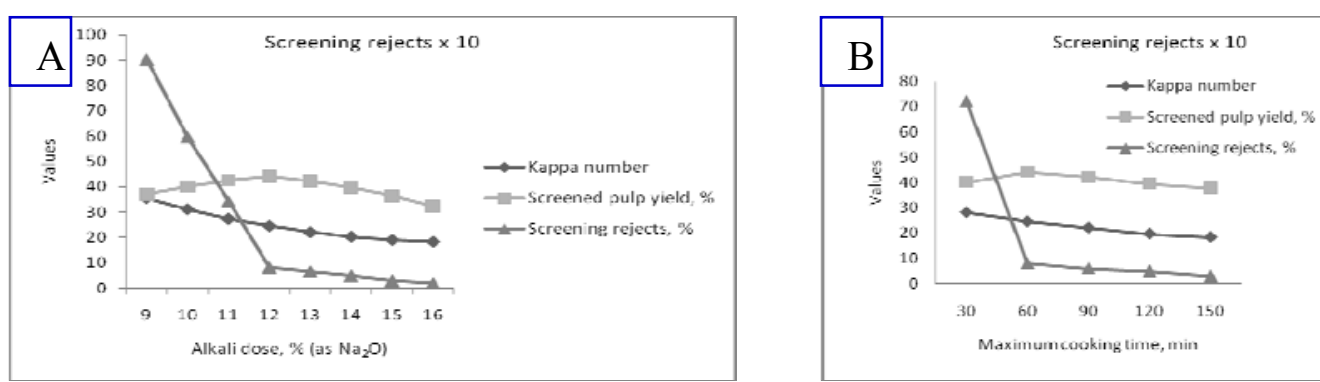

Fig. 3. (A) Effect of alkali dose on screened pulp yield, screening rejects and kappa number (B) Effect of maximum cooking time on screened pulp yield, screening rejects and kappa number during soda pulping of wheat straw

\section{Influence of $A Q$}

Figure 4 shows the effect of anthraquinone (AQ) at different alkali doses, i.e. 10$12 \%$ (as $\mathrm{Na}_{2} \mathrm{O}$ ), while keeping other conditions constant during soda pulping of wheat straw. The addition of AQ at a dose of $0.1 \%$ increases the screened pulp yield, and it decreases screening rejects and kappa number when applied at different alkali doses, i.e. $10-12 \%$ (as $\mathrm{Na}_{2} \mathrm{O}$ ). AQ improves the pulp yield by $0.75 \%$, and mitigates the kappa number by $26.1 \%$ at optimum cooking alkali charge of $12 \%\left(\right.$ as $\left.\mathrm{Na}_{2} \mathrm{O}\right)$ for soda pulping. The increase in pulp yield and reduction in kappa number can be explained on the basis of the redox catalytic activity of AQ. AQ is a pulping additive that accelerates delignification and protects carbohydrates against degradation. It works through a cycle, which leads to the reduction of lignin and the oxidation of the reducing end group of cellulose from an aldehyde to a carboxylic acid. In the latter case the carbohydrates are stabilized against the alkaline peeling reactions, by means of the so-called stopping reaction, leading to an increase in pulp yield. Because AQ goes through a cyclic process, it is typically used at about $0.1 \%$ on o.d. raw material basis, and results in an increase in pulp yield (Buchanan et al. 2000). 
Table 5 reveals the mechanical strength properties of unbleached soda and sodaAQ pulps of wheat straw cooked at different alkali doses i.e. 10-12\% (as $\left.\mathrm{Na}_{2} \mathrm{O}\right)$, and beaten at different beating levels i.e. 19-55 ${ }^{\circ} \mathrm{SR}$. All the mechanical strength properties show an improving trend up to an alkali dose of $12 \%\left(\right.$ as $\left.\mathrm{Na}_{2} \mathrm{O}\right)$, and beating level of 45 ${ }^{\circ} \mathrm{SR}$, beyond which there is a slight decrease in mechanical strength properties.

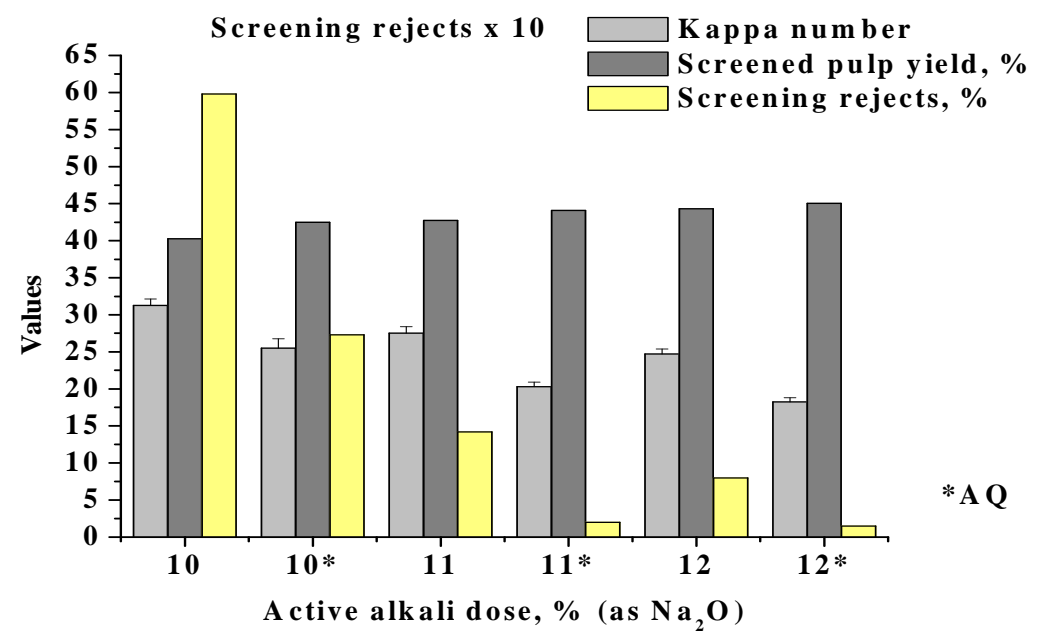

Fig.4. Effect of anthraquinone on screened pulp yield, screening rejects and kappa number at different alkali doses at optimum pulping conditions during soda pulping of wheat straw

Figures $5 \mathrm{~A}$ and $\mathrm{B}$ show that the burst index, tensile index, and double fold improve with increase in beating level up to a beating level of $45 \pm 1{ }^{\circ} \mathrm{SR}$, but the tear index first improves and then declines sharply. The reason is that the work done on pulling the short fibers out of a sheet is less than that required to break the fibers. Thus, as the inter-fiber bonding increases, and the proportion of fiber that is fractured rather than pulled out rises, the tear index increases to a constant value, i.e. $3.90 \mathrm{mNm}^{2} / \mathrm{g}$ for soda pulp (Fig. 5A), and $4.25 \mathrm{mNm}^{2} / \mathrm{g}$ (Fig. 5B) for soda-AQ pulp, which presumably represents the work done in fracturing the fibers. Initially, the mechanical strength properties depend upon the fiber length. The degradation of carbohydrate fractions beyond optimum alkali dose causes the decline of mechanical strength properties. All the mechanical strength properties are found to increase with increasing beating level up to $45{ }^{\circ} \mathrm{SR}$, except for tear strength. The removal of primary wall exposes secondary wall layers. However, primary wall is permeable to water but does not participate in bond formation. Therefore, tearing energy required to pull the fibers from the mesh is slightly more due to hydrogen bonding after removal of the primary wall. Further, due to cutting action, external and internal fibrillations, and brushing action, tear strength declines, but all other properties that are dependent upon hydrogen bonding are improved with pulp beating.

Fiber length distribution of wheat straw

Table 6 shows the fiber length distribution of soda-AQ pulp of wheat straw at 220 CSF (Canadian Standard Freeness). Important quantitative information about the fiber 
length distribution of a wheat straw pulp can be best achieved by fiber fractionation. Furthermore, while using the Bauer-McNett fiber classifier with screens of 20,48, 100, and 200 mesh size, the fractionation not only separates the fibers according to the fiber length, but also, to a great extent, it separates the fractions of sclerenchyma fibers, and parenchyma cells. The +20 fractions comprised $12.16 \%$ of the total, and it consisted of mostly long sclerenchymatous fiber. The +48 fractions involved $40.31 \%$ of pulp of the medium sized fiber. The +100 fractions retained $21.21 \%$ of the total pulp with the short-ened fibers, parenchyma cells, large vessel fragments, while the +200 fractions contained $0.92 \%$ of pulp having short parenchyma cells, and other short material, and fragments of the epidermal tissue. The -200 fractions involve $25.40 \%$ of the pulp, and include the fiber, and cell debris, single epidermal cells and collenchyma cells (Hegbom 1992).

Table 5. Mechanical Strength Properties of Soda and Soda-AQ Unbleached Wheat Straw Pulps at Different Alkali Doses and Beating Levels

\begin{tabular}{|c|c|c|c|c|c|}
\hline $\begin{array}{l}\text { Active alkali, } \\
\% \quad \text { (as } \\
\left.\mathrm{Na}_{2} \mathrm{O}\right)\end{array}$ & $\begin{array}{l}\text { Beating level, } \\
\text { 'SR }\end{array}$ & $\begin{array}{l}\text { Tensile index, } \\
\mathrm{Nm} / \mathrm{g}\end{array}$ & $\begin{array}{l}\text { Tear index, } \\
\mathrm{mNm}^{2} / \mathrm{g}\end{array}$ & $\begin{array}{l}\text { Burst index, } \\
\mathrm{kPam}^{2} / \mathrm{g}\end{array}$ & $\begin{array}{l}\text { Double fold, } \\
\text { no. }\end{array}$ \\
\hline \multirow{4}{*}{10} & 19 & 18.85 & 3.07 & 0.75 & 5 \\
\hline & $35 \pm 1$ & 45.32 & 4.21 & 2.55 & 35 \\
\hline & $45 \pm$ & 64.84 & 3.42 & 3.35 & 40 \\
\hline & $55 \pm 1$ & 64.12 & 3.12 & 3.45 & 42 \\
\hline \multirow{4}{*}{$10 *$} & $19 \pm 1$ & 19.10 & 3.15 & 0.90 & 6 \\
\hline & $35 \pm 1$ & 46.00 & 4.35 & 2.72 & 32 \\
\hline & $45 \pm 1$ & 65.75 & 3.21 & 3.42 & 43 \\
\hline & $55 \pm 1$ & 64.90 & 3.10 & 3.51 & 45 \\
\hline \multirow{4}{*}{11} & 19 & 20.15 & 3.65 & 0.85 & 6 \\
\hline & $35 \pm 1$ & 47.21 & 4.41 & 2.65 & 37 \\
\hline & $45 \pm 1$ & 66.90 & 4.06 & 3.47 & 67 \\
\hline & $55 \pm 1$ & 66.20 & 3.70 & 3.55 & 70 \\
\hline \multirow{4}{*}{$11^{*}$} & $19 \pm$ & 21.35 & 3.75 & 1.02 & 5 \\
\hline & $35 \pm 1$ & 47.90 & 4.55 & 2.72 & 41 \\
\hline & $45 \pm 1$ & 67.12 & 4.15 & 3.92 & 71 \\
\hline & $55 \pm 1$ & 66.90 & 3.50 & 4.02 & 75 \\
\hline \multirow{4}{*}{12} & 19 & 22.35 & 3.86 & 1.10 & 8 \\
\hline & $35 \pm 1$ & 48.71 & 4.96 & 3.52 & 70 \\
\hline & $45 \pm 1$ & 68.25 & 4.12 & 3.90 & 81 \\
\hline & $55 \pm 1$ & 67.25 & 3.24 & 3.86 & 85 \\
\hline \multirow{4}{*}{$12^{*}$} & 19 & 23.75 & 3.55 & 1.15 & 7 \\
\hline & $35 \pm 1$ & 50.08 & 5.10 & 3.76 & 71 \\
\hline & $45 \pm 1$ & 69.75 & 4.02 & 4.25 & 89 \\
\hline & $55 \pm 1$ & 68.12 & 3.15 & 4.21 & 85 \\
\hline
\end{tabular}

Cooking conditions: Liquor to raw material ratio $=4: 1$, maximum temperature, ${ }^{0} \mathrm{C}=150$, time from ambient to $105{ }^{\circ} \mathrm{C}, \min =30$, time from 105 to maximum temperature, $\min =30$ and time at maximum temperature, $\min =60,{ }^{*} 0.1 \% \mathrm{AQ}$ dose (on od raw material basis) 

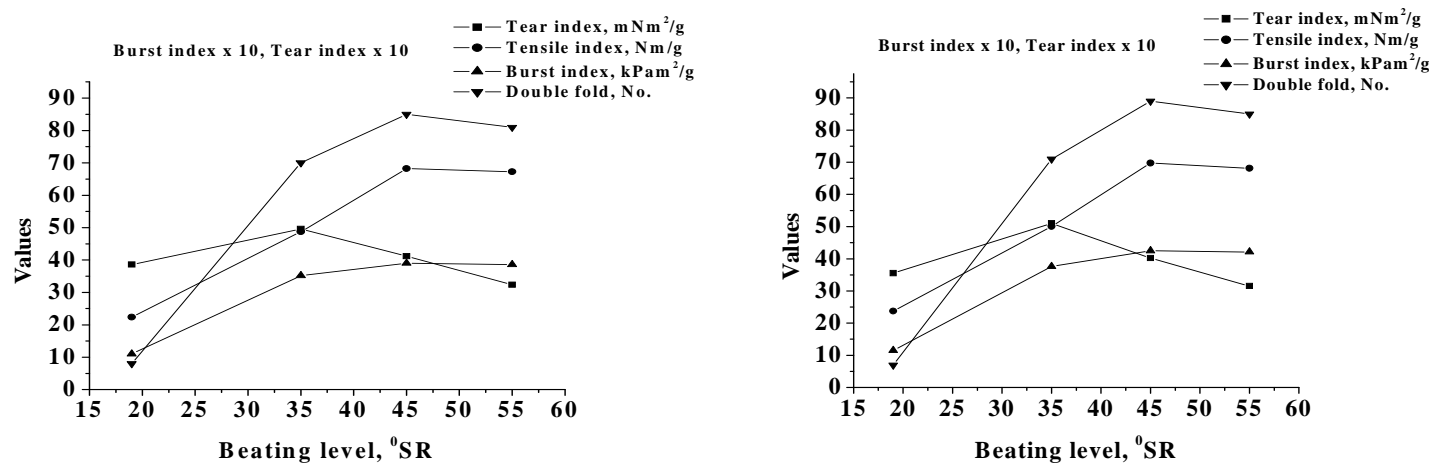

Fig.5. (A) Plots of mechanical strength properties vs beating levels ( $\left.{ }^{\circ} \mathrm{SR}\right)$ of soda pulp of wheat straw at $10 \%$ active alkali dose; (B) Plots of mechanical strength properties vs beating levels ( ${ }^{\circ} \mathrm{SR}$ ) of soda-AQ pulp of wheat straw at $10 \%$ active alkali dose

\section{Studies on fiber deformation}

The soda-AQ wheat straw pulp samples were also studied for fiber deformations, and the results are reported in Table 7 . While the kink index of wheat straw was about 4.4\% higher than that reported for Eucalyptus tereticornis, the curl index was found to be similar in both cases at 0.141 . Kinks per mm reported for wheat straw fibers were a little higher (by 7.5\%) as compared to Eucalyptus tereticornis. Shives per mm for wheat straw pulp are reported to be 9.78. Thus, though the fine content of wheat straw pulp is much higher, it was found to be more or less comparable in quality to Eucalyptus tereticornis in terms of curl index and kinks per mm.

Table6. Bauer-McNett Fiber Classification of Soda-AQ Wheat Straw Pulp at Optimum Pulping Conditions

\begin{tabular}{|c|c|c|}
\hline $\begin{array}{c}\text { Sl. } \\
\text { No. }\end{array}$ & Mesh size & Fractions, \% \\
\hline 1. & +20 & 12.16 \\
\hline 2. & $-20+48$ & 40.31 \\
\hline 3. & $-48+100$ & 21.21 \\
\hline 4. & $-100+200$ & 0.92 \\
\hline 5. & -200 & 25.4 \\
\hline
\end{tabular}

\section{Microscopy}

Photomicrograph 3A shows a smooth, slender wheat straw pulp fiber having a thick cell wall and a narrow lumen. Such fibers readily conform during beating, and they contribute to paper strength. The presence of different types of cells in the wheat straw pulp gives it a heterogeneous character. These different types of cells include parenchyma cells and vessels (Photomicrograph 3B). The cell wall is distinguished by longitudinal striations and transverse fractures with somewhat swollen fissures, which are conspicuous. The fibers are rectangular in shape; they are moderately thin to thick walled (Photomicrograph 3C). Photomicrograph 3D shows that the wheat straw fibers are entangled with unseparated flakes and epidermal cells, which are resistant to pulping. The flakes entangled with fibers present on the surface of paper sheet are deposited on press rolls or dryers of paper machine or deposited on printing blankets during offset printing 
due to loose bonding and created fluff generation. Photomicrograph 4A shows that the fibers of soda-AQ pulp of wheat straw have rough surface with swelling, peeling and cracks (Photomicrograph 4B). Photomicrograph 4C shows flattened wheat straw fiber having a ribbon-shaped conformation.

Table7. Analysis of Wheat Straw Pulp for Fiber Deformations by
Fiber Quality Analyzer (FQA)
\begin{tabular}{|l|c|c|}
\hline Properties & Wheat straw soda-AQ pulp & $\begin{array}{c}\text { Eucalyptus tereticornis } \\
\text { (Anonymous, 2002) }\end{array}$ \\
\hline Mean curl index & 0.141 & 0.141 \\
Arithmetic & 0.152 & - \\
Length weighted & & 2.15 \\
\hline Mean kink index & 2.25 & 29.93 \\
Kink index (1/mm) & 38.75 & 0.98 \\
Total kink angle (degrees) & 1.06 & 25.59 \\
Kinks per mm (1/mm) & & 5.34 \\
\hline Percent fines & - & - \\
Arithmetic & & \\
Length weighted & 9.78 & \\
\hline Number of shives/mm & & \\
\hline
\end{tabular}

${ }^{\mathrm{a}}$ Fiber Quality Analyzer Model V1.3REB19CV-M 4, ${ }^{\mathrm{b}}$ Total fiber count $=8965.00$

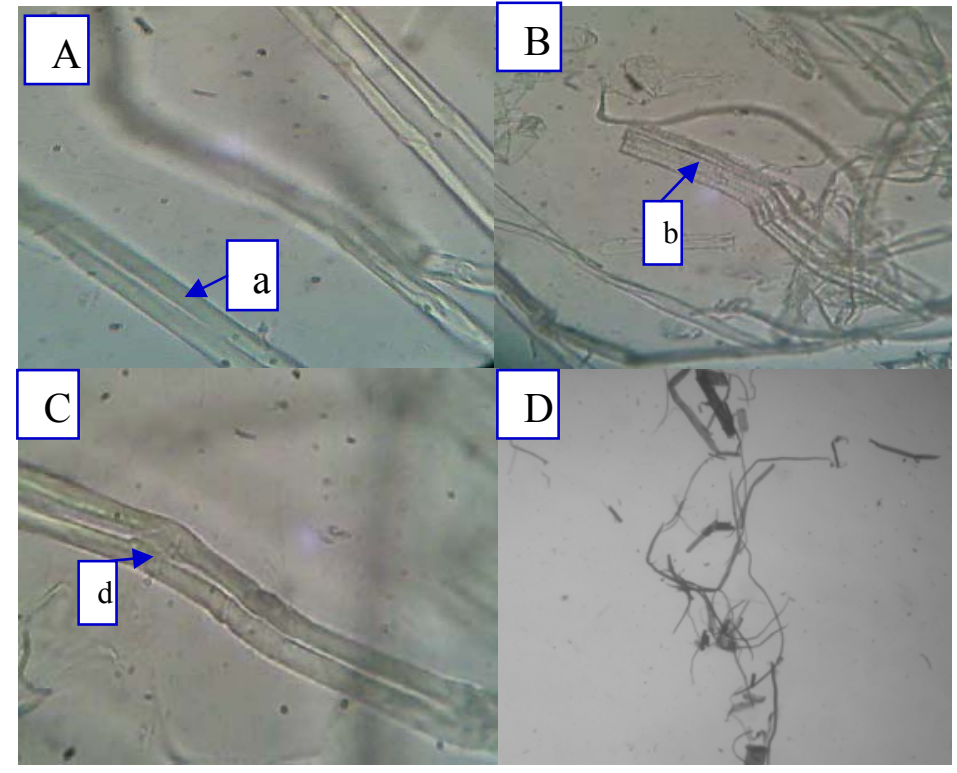

Photomicrograph 3. Showing (A) wheat straw fibers with lumen of variable thickness: (a) (40x); (B) a parenchyma cell (40x) (b); (C) wheat straw fiber with extremely narrow lumen, transverse fractures and swollen fissures (d) (40x); (D) unseparated flakes, parenchyma and other cell types entangled with (4x) 


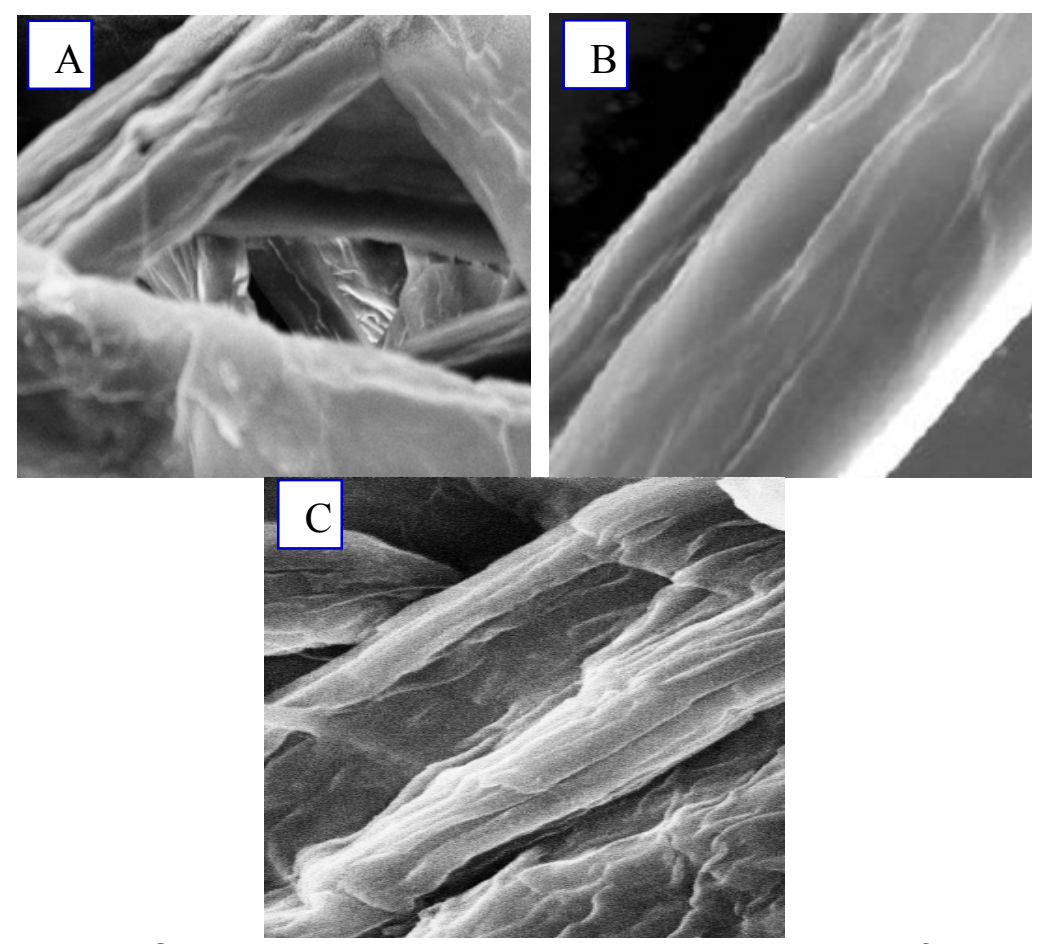

Photomicrograph 4. Scanning electron micrograph showing: (A) unfibrillated wheat straw fibers with flattened surface (3.5 kx); (B) wheat straw fibers without external fibrillation, after sodaAQ pulping, (2000x); (C) flattened wheat straw fiber having a ribbon-shaped conformation, $2.5 \mathrm{kx}$.

\section{CONCLUSIONS}

Triticum aestivum PBW-343 is grown in most of the regions of India; hence, it has potential to be one of the significant renewable resources of short fibers for pulp and paper applications. The total fibers in wheat straw are about $39.20 \%$, whereas parenchyma and epidermal cells account for about 32.10 and $23.56 \%$ of the total cells, respectively. The vessels account for about $5.14 \%$ of the total cells. The dimensions of these non-fibrous cells lie between those of rice straw and bagasse. There, the slot size intended for pulp screening of wheat straw pulp cannot be used for sugarcane bagasse and rice straw. The morphological characteristics, i.e. flexibility coefficient and Runkal ratio of wheat straw fibers resemble to those of bamboo fibers due to less fiber diameter and shorter fiber length. The sheet made from such types of fibers give more tear, porosity, bulk, and opacity. The mechanical properties along with other properties of paper related to wet plasticity may be increased by the presence of high hemicelluloses (28.95\%). The high hemicelluloses affect the hemicelluloses to cellulose ratio, so the paper is weaker. The water-soluble matter in wheat straw is higher compared sugarcane bagasse and rice straw. The high $\mathrm{NaOH}$ solubility of wheat straw is higher due to the presence of low molar mass carbohydrates, and other alkali soluble materials. Therefore, it cannot be stored for a long time. Wheat straw has a total carbohydrate fraction (holocellulose) approximately equal to that of hardwood due to the high hemicelluloses (mainly pentosan). It contains low lignin contents; this means that it requires moderate 
pulping conditions to reach satisfactory kappa number. The biomass contains higher proportions of hydrogen and carbon, which increases the energy value. Wheat straw produces a screened pulp yield $44.30 \%$ of kappa number 24.70 at an active alkali charge of $12 \%\left(\right.$ as $\left.\mathrm{Na}_{2} \mathrm{O}\right)$, maximum cooking temperature of $150{ }^{\circ} \mathrm{C}$, maximum cooking time 60 min, and liquor to raw material ratio $4: 1$. AQ improves the pulp yield by $0.75 \%$, and it lowers the kappa number by $26.1 \%$ at an optimum cooking alkali charge of $12 \%$ (as $\mathrm{Na}_{2} \mathrm{O}$ ) for soda pulping. Optimum mechanical strength properties are obtained at a beating level up to $45^{\circ} \mathrm{SR}$. Kinks per mm and fine content of wheat straw pulp are much higher. In this regard, wheat straw pulp is found to be more or less comparable in quality to Eucalyptus tereticornis in terms of curl index and kinks per mm. The kinks can be removed by beating or refining to some extent as a result of increasing fiber flexibility. SEM micrographs show that the fibres of wheat straw soda-AQ pulp are smooth and slender, having a thick cell wall and a narrow lumen. Such fibers easily conform to each other after beating, and contributing to paper strength.

\section{REFERENCES CITED}

Akhtar, R. S., (2000). "Studies on pulping and bleaching of Poplar deltoides, PhD Thesis, University of Roorkee, India.

Agnihotri, S., Dutt, D., and Tyagi, C. H. (2010). "Complete characterization of bagasse of early species of Saccharum officinerun-Co 89003 for pulp and paper making," BioResources 5(2), 1197-1224.

Alcaide, L. J., Baldovin, F. L., and Heranz, J. L. F. (1993). "Evaluation of agricultural residues for paper manufacture,” Tappi J. 76(3), 169-173.

Anonymous, (1996). "Basic properties of papermaking fibres and fibre fines important to wet end chemistry," In: Scott, W. E., (Ed.), Principles of Wet End Chemistry, Tappi press, Atlanta GA, 11-17.

Anonymous, (2002). "Preparation of monograph of different nonwood raw materials used by Indian Paper Industry," CESS Report published by CPPRI.

Anonymous, (2005a). "Statistics of the Indian paper industry; Paper, paperboard and newsprint," A Report by CPPRI, pp 3-23.

Anonymous, (2005b). "Solid biofuels- Determination of total amount of carbon hydrogen and nitrogen- Instrumental methods," DD CEN/TS 15104.

Anonymous, (2007). "TAPPI Test Methods," Standard Methods for Pulp and Paper, Technical Association of Pulp and Paper Ind., TAPPI Press, Technology Park, P.O. box 105113, Atlanta, GA-330348-5113, USA.

Buchanan, B. B., Gruissem, W., and Jones, R. L. (2000). "Biochemistry and molecular biology of plants," (1 ${ }^{\text {st }}$ Edn.), American Society of Plant Physiologists, Rockville, MD.

Chand, R., Arun, B., and Singh G. (2003). "Wheat improvement in eastern and warmer regions of India: Conventional and non-conventional approaches," A compendium of the training program (26-30 December, 2003), NATP project, (ICAR), BHU, Varanasi, India.

Demirbas, A. (1997). "Calculation of higher heating values of biomass fuels," Fuel 76, 431-434. 
Deniz, İ. (1994). “Bŭgday Saplarının (Triticum aestivum L.),” In: Ön desilikasyonu ve bu işlemin soda-oksijen kaǵıt hamurları üzerine etkisi, Doktora Tezi, KTÜ Orman Fak., $201 \mathrm{~s}$.

Dutt, D. (1994). "Pulping studies on Cannabis sativa and Ipomea carnea," Ph.D. Thesis, University of Roorkee, India.

Dutt, D., Garg, A. P., Tyagi, C. H., Upadhyay, A. K., and Upadhyay, J. S. (2007). "Biosoda-ethanol-water (BIO-SEW) delignification of lignocellulosic residues of Cymbopogon martini with Phanerochaete chrysosporium," J. Cellulose Chem. Technol. 41 (2-3), 161-174.

Dutt, D., and Tyagi, C. H., (2010a). "Studies on Ipomea carnea and Cannabis sativa as an alternate pulp blend for softwood: Optimization of soda pulping process," J. Sci. Ind. Res. 69 (6), 460-467.

Dutt, D., Tyagi, C. H., Agnihotri, S., Kumar, A., and Siddhartha, (2009a). "Alkoxygen and alkoxygen-AQ delignification of Ipomea carnea and Cannabis sativa," Indian J. Chem. Technol. 16(6), 523-528.

Dutt, D., Tyagi, C. H., Agnihotri, S., Kumar, A., and Siddhartha, (2010d). "Bio-soda pulping of lignocellulosic residues of palma rosa grass: An attempt towards energy conversion," Indian J. Chem. Technol. 17(1), 60-70.

Dutt, D., Tyagi, C. H., and Malik, R. S., (2007b). "Studies on effect of growth factor on morphological, chemical and pulp and paper making characteristics and its impact on fluff generation," Indian J. Chem. Technol. 14 (6), 626-634.

Dutt, D., and Upadhyaya, J. S. (1994). "Studies on alkoxygen and alkoxygenanthraquinone delignification of Ipomea carnea," Research and Industry 39 (9), 202208.

Dutt, D., Upadhyaya, J. S., Malik, R. S., and Tyagi, C. H., (2004). "Studies on pulp and paper-making characteristics of some Indian non-woody fibrous raw materials: PartII," J. Sci. Ind. Res. 63(2), 58-67.

Dutt, D., Upadhyaya, J. S., Malik, R. S., and Tyagi, C. H., (2005). "Studies on pulp and paper-making characteristics of some Indian non-woody fibrous raw materials: PartI," J. Cellulose Chem. Technol. 39(1-2), 115-128.

Dutt, D., Upadhyaya, J.S., Singh, B., and Tyagi, C. H., (2009b). "Studies on Hibiscus cannabinus and Hibiscus sabdariffa as an alternative pulp blend for softwood: An optimization of kraft delignification process," Ind. Crops Products 29, 16-26.

Dutt, D., Upadhyaya, J. S., Tyagi, C. H., and Kumar, A., (2008). "Studies on Ipomea carnea and Cannabis sativa as an alternative pulp blend for softwood: An optimization of kraft delignification process," Ind. Crops Products 28, 128-136.

Dutt D., Upadhyaya, J. S., and Tyagi, C. H., (2010b). "Studies on Hibiscus cannabinus, Hibiscus sabdariffa and Cannabis sativa pulp to be a substitute for softwood pulp-Part 1: AS-AQ delignification process," BioResources 5(4), 2123-2136.

Dutt D., Upadhyaya, J. S., and Tyagi, C. H. (2010c). "Studies on Hibiscus cannabinus, Hibiscus sabdariffa and Cannabis sativa pulp to be a substitute for softwood pulp-Part 2: SAS-AQ and NSSC-AQ delignification process," BioResources 5(4), 2137-2152.

Kaur, H., Dutt, D., and Tyagi, C. H. (2011). "Optimization of soda pulping process of ligno-cellulosic residues of lemon and sofia grasses produced after steam distillation," BioResources 6(1), 103-120. 
Erŏglu, H., and Utsa, M. (1989). "Oxygen bleaching of soda-oxygen wheat straw pulp," TAPPI Non-wood Plant Fibre Pulping, Progress Report No. 19, pp. 89-94.

Erŏglu, H., and Deniz, İ. (1998). " $\mathrm{O}_{2}-\mathrm{NaOH}$ pulping of predesilicated wheat straw (Triticum aestivum L.)," Inpaper Int. 2 (5), 14-20.

FAO (2004) "Statistical database," www.fao.org. Verified 4 January, 2007 Fischer RA (1985).

Flynn, B. (2007). "Shape of things to come," Pulp Paper Intl. 12, 1.

Gabriel, B. L. (1982). Biological Scanning Electron Microscopy, Von Nostrand Reinhold Company, New York, Toronto, London, Melbourne.

Goyal, S. K., and Ray, A. K. (1989). "Economic comparison of soda and soda-AQ pulping processes for cereal straws," Tappi Pulping Conference, Seattle, 775-780.

Guo, S., Heijnesson-Hultén, A., Basta, J., and Greschik, T. (2009). "Pulp and fiber characterization of wheat straw and eucaluptys pulp - A comparison," BioResources 4(3), 1006-1016.

Gupta, R. K., (2004). "Quality of Indian wheat and infrastructure for analysis," In: Breeding Crops for Reduced-Tillage Management in the Intensive, Rice-Wheat Systems of South Asia, Euphytica 153, 135-151

Han, J. S., Mianowski, T., and Lin, Y. (1999). "Validity of plant fibre length measurement - A review of fibre length measurement based on kenaf as a model," In: Sellers, T., Reichert, N. A., (eds.), Kenaf Properties, Processing and Products, Mississippi State University, 149-167.

Hegbom, L., (1992). "Structural aspects of sugar-cane bagasse from a paper-making point of view: A light microscopic study," Second international non-wood fibre pulping and papermaking conference proceedings, Shanghai International Trade Centre, Shanghai, 657-672.

Hes, C. Y., and Kuo, M. L. (1988). "Influence of extractives on wood gluing and finishing - A review," Forest Prod. J. 38, 52-56.

Hinrichs, D. D. (1967). "The effect of kraft pulping variables on delignification," Tappi J. 50 (4), 173-175.

Hurter, R. W. (1997) “Non-wood plant fibre characteristics,” In: TAPPI 1997 Short Course Notes, TAPPI, Atlanta, USA, pp. 1-11.

Ilvasasslo-Pfäffli, M. S. (1995). Fibre Atlas, Identification of Papermaking Fibres, Springer, New York.

Jacobs, R. S. (1999). "The Paper making properties of Washington state wheat straw," $\mathrm{PhD}$, University of Washington, Graduate School, UMI Number 9936427, USA.

Kleinert, T. N. (1965). "Discussion of results and the principles of rapid delignification, Part-VI of a series of alkaline pulping studies," Tappi J. 48 (8), 447-451.

Lal, M., Dutt, D., Tyagi, C. H., Siddarth, and Upadhyaya, J. S. (2010). "Characterization of Anthocephalus cadamba and its delignification by kraft pulping," Tappi J. 9(3), 30-37.

Ljusgren, I., Wiberg, B., Tubek Lindblom, A., and Persson, T. (2006). "Papermaking potentialof Scandinavian softwood pulp together with non-wood pulp," In: New Technologiesin Non-wood Fiber Pulping and Papermaking, 5th INWFPPC, Guangzhou, China, pp. 281-286. 
Loxton, C., and Hague, J. (1996). "Utilization of agricultural crop materials in panel products," In: Proceedings, No.7286 the Use of Recycled Wood and Paper in Building Applications, Forest Products Society, Madison, WI, pp. 190-192.

Maiti, R. (1997). World Fibre Crops, Science Publishers, 105-108.

Malik, R. S., Dutt, D., Tyagi, C. H., Jindal, A. K., and Lakharia, L. K. (2004).

"Morphological, anatomical and chemical characteristics of Leucaena leucocephala and its impact on pulp and paper making properties," J. Sci. Ind. Res. 63(2), 125133.

Marton, J., and Marton, T. (1980). "Wet end starch: Adsorption of starch on cellulosic fibres," Tappi J. 63 (4), 87-91.

Nagarajan, S. (2005). “Can India produce enough wheat even by 2020?” Curr. Sci. 89, 146-147.

Nevell, T. P., and Zeronian, S. H. (1985). "Cotton fibres," In: Cellulose Chemistry and its Applications, John Wiley \& Sons, New York, Halsted Press, 552.

Nguyen, T., and Johns, W .E. (1979). "The effects of aging and extractives on the surface free energy of Douglas-fir and red wood," Wood Sci. Technol. 13, 29-40.

Nieschlag, H. J., Nelson, G. H., Wolff, J. A., and Purdue, R. E. (1960). “A search for new fibre crops," Tappi J. 43 (3), 193-201.

Nussbaumer, T., (2002). "Combustion and co-combustion of biomass," In: Proceedings of the $12^{\text {th }}$ European Biomass Conference, Vol. 1, pp. 31-37, ISBN: 88900442-5-x.

O’Brien, J. (2006). "Paper demand continues to grow," Paper Age 122 (6), 1.

Ogbonnaya, C. I., Roy-Macauley, H., Nwalozie, M. C., and Annerose, D. J. M. (1997). "Physical and histochemical properties of kenaf (Hibiscus cannabinus L.) grown under water deficit on a sandy soil," Ind. Crops Products 7, 9-18.

Payton, J. H., and Canaris, N. M. (1997). "Bleaching compositions and processes employing sulfamates and polyaminocarboxylic acids - US Patent," http://www.patentstorm.us/patents/5645688.

Pillow, M. Y., Chidester, G. H., and Bray, M. W. (1941). "Effect of wood structure on properties of sulphate and sulphite pulps from loblolly pine," South Pulp and Paper J., 4(7), 6 .

Reddy, N., and Yang, Y. (2005). "Biofibres from agricultural by products for industrial applications," Trends in Biotechnology 23(1), 22-27.

Rydholm, S. A. (1965). Pulping Processes, Wiley, New York, Preprint 1985 (facsimile edition) Robert E. Krieger, Malabar, FL, pp. 1270.

Sauter, S. L. (1996). "Developing composites from wheat straw," In: Proceedings, $30^{\text {th }}$ International Particleboard/Composite materials Symposium, Washington State University, Washington, USA, pp. 197-214.

SCAN Test Methods, (1978). "SCAN-C9:62-Determination of ash and silica," Scandinavian Pulp, Paper and Board Committee, Sweden.

Scott, W. E. (1996). "Basic properties of papermaking fibres and fibre fines important to wet end chemistry," In: Scott, W.E., (Ed.), Principles of Wet End Chemistry, TAPPI Press, Atlanta GA, 11-17.

Tandon, R., Gupta, A., Kulkarni, A. G., and Panda, A., (1989). "Properties of black liquors from pulping of nonwood raw materials," In: International Seminar and Workshop on Desilication, Proceedings of the International Seminar, Cochin, 23-35. 
Thykesson, M., Sjöberg, L.-A., and Ahlgren, P. (1998). "Paper properties of grass and straw pulps," Ind. Crops Prod. 7, 351-362.

Tyagi, C. H., Dutt, D., Pokharel, D., and Malik, R. S. (2004). "Studies on soda and soda AQ pulping of Eulaiopsis binata," Indian J. Chem. Technol. 11(1), 127-134.

Upadhyaya, J. S., Dutt, D., Singh, B., and Tyagi, C. H., (2008). "Studies on Hibiscus cannabinus and Hibiscus sabdariffa as an alternative pulp blend for softwood: An optimization of soda pulping process," Indian J. Chem. Technol. 15(3), 277-286.

Watson, P., and Garner, A. (1997). "The opportunities for producing pulp from agricultural residues in Alberta," In: A Review of Non-Wood Pulping Technologies, Pulp and Paper Research Institute of Canada, Miscellaneous Report, MR 355.

Young, R. A. (1976). "Wettability of wood pulp fiber," Wood Fiber Sci. 8, 120-128.

Article submitted: September 8, 2010; Peer review completed: November 19, 2010; Revised version received and accepted: November 24, 2010; Published: November 26, 2010. 